\title{
Persepsi Kesiapan Mahasiswa Akuntansi dalam Menghadapi Tantangan di Era Revolusi Industri 4.0
}

\author{
Ni Luh Putu Norma Dewi Abdi Pradnyani' ${ }^{1}$ \\ Jurusan Akuntansi \\ Politeknik Negeri Bali, Indonesia
}

\author{
I Gusti Ayu Astri Pramitari² \\ Jurusan Akuntansi \\ Politeknik Negeri Bali, Indonesia
}

\author{
I Nyoman Abdi ${ }^{3}$ \\ Jurusan Akuntansi \\ Politeknik Negeri Bali, Indonesia
}

\begin{abstract}
Surel : normadewi27@pnb.ac.id
ABSTRAK

Penelitian ini mengkaji pengaruh pemahaman akuntansi, soft skill, pengetahuan teknologi informasi terhadap kesiapan akuntan dalam menghadapi tantangan era revolusi industri 4.0. Penelitian ini menggunakan data primer berupa kuisioner yang berisi pernyataan terkait variabel penelitian, pengumpulan data menggunakan teknik purposive sampling yaitu sampling dengan kriteria tertentu. Sampel dalam penelitian ini yaitu mahasiswa semester akhir jurusan akuntansi Politeknik Negeri Bali. Jumlah sampel pada penelitian ini adalah 137 sampel. Data hasil penyebaran kuisioner selanjutnya dianalisis secara statistik menggunakan program SPSS dengan alat analisis regresi linear berganda, uji asumsi klasik, uji $\mathrm{T}$ dan uji $\mathrm{F}$, serta koefisien determinasi. Hasil pengujian menunjukkan adanya pengaruh positif signifikan antara pemahaman akuntansi, soft skill, dan pengetahuan teknologi informasi terhadap kesiapan menghadapi tantangan era revolusi industri 4.0.
\end{abstract}

Kata Kunci: Pemahaman Akuntansi; Pengetahuan Teknologi Informasi; Soft skill; Era Revolusi Industri 4.0.

\section{Perception Of Readiness Of Accounting Students In Facing Challenges In The Era Of Industrial Revolution 4.0}

\section{ABSTRACT}

This research examines the influence of accounting understanding, soft skills, information technology knowledge on the readiness of accountants in facing the challenges of the industrial revolution era 4.0. This study uses primary data in the form of questionnaires that contain statements related to research, data collection using purposive sampling techniques that are sampling with certain criteria. The sample in this study is the final semester students majoring in accounting of Bali State Polytechnic. The number of samples in this study was 137 samples. The questionnaire deployment data is statistically analyzed using the SPSS program with multiple linear regression methods, classical assumption tests, $T$ and $F$ tests, and coefficients of determination. The test results showed a significant positive influence between accounting understanding, soft skills, and information technology knowledge on readiness to face the challenges of the industrial revolution era 4.0.

Keywords: Accounting Understanding; Soft skills; IT Comprehension; Industry 4.0.

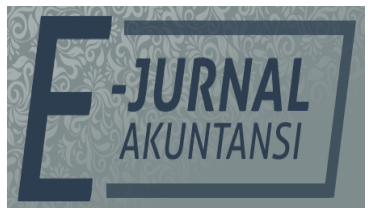

e-ISSN 2302-8556

Vol. 31 No. 10

Denpasar, Oktober 2021

Hal. 2582-2596

DOI:

10.24843/EJA.2021.v31.i10.p14

PENGUTIPAN:

Pradnyani, N.L.P.N.D.A., Pramitari, I.G.A.A., \& Abdi, I.N. (2021). Persepsi Kesiapan Mahasiswa Akuntansi dalam

Menghadapi Tantangan di

Era Revolusi Industri 4.0. EJurnal Akuntansi, 31(10), 2582-2596

RIWAYAT ARTIKEL: Artikel Masuk: 18 Juni 2021 Artikel Diterima: 22 Oktober 2021

Artikel dapat diakses : https://ojs.unud.ac.id/index.php/Akuntansi/index 


\section{PENDAHULUAN}

Perkembangan teknologi selalu beriringan dengan perkembangan zaman dan menjadi hal yang selalu berubah serta tidak dapat dihindari oleh manusia. Perubahan yang terjadi saat ini di semua lini kehidupan mengakibatkan munculnya berbagai teknologi yang dapat membantu mempermudah pekerjaan manusia saat ini (Merlina \& Nuraini, 2020). Globalisasi dan perkembangan zaman membuat dunia khususnya dunia usaha dan profesi berkembang sangat pesat. Efek globalisasi ini berdampak pada seluruh dunia, termasuk di Indonesia, yakni terlihat dari akses internet yang semakin terintegrasi. Kondisi ini secara positif memicu adanya peluang-peluang baru yang dapat menjadi ladang bisnis bagi generasi saat ini (Latifah et al., 2020).

Industry 4.0 atau era revolusi industri 4.0 menunjukkan perkembangan yang kian luas hingga Indonesia dan negara berkembang lainnya. Kemajuan industri ini dicirikan dengan berbagai bentuk perkembangan teknologi, misalnya teknologi GMO dalam sustainabilitas pangan, sistem penyimpanan berbasis cloud dalam dunia komputer, mobil pintar dalam dunia otomotif, hingga customer service yang beranjak mulai menggunakan robot (Merlina \& Nuraini, 2020). Termasuk salah satu yang sedang berkembang pesat adalah artificial intellegent/AI (Fauzan, 2020). Contoh sederhananya dalam dunia virtual adalah Siri pada perangkat iOS dan Google Assistant pada perangkat Android. Industry 4.0 membawa perubahan bersamaan pula segala konsekuensinya, muncul berbagai peluang dan secara bersamaan muncul pula berbagai tantangan yang mengikutinya. Tantangan terbesar dalam revolusi industri adalah tenaga kerja manusia yang selama ini digunakan akan mulai tergantikan dengan tenaga robot (sistem otomatisasi). Konsekuensinya, angka pengangguran berpotensi mengalami peningkatan (Latifah et al., 2020), di mana hal tersebut sudah terlihat saat ini.

Industry 4.0 pada dasarnya mengintegrasikan teknologi dengan bisnis, sehingga secara tidak langsung akan menggeser ketergantungan industri akan SDM atau sumber daya manusia. Dalam beberapa bidang, kebutuhan SDM saat ini telah tergantikan oleh teknologi kecerdasan buatan dalam berbagai bentuk. Sehingga, manusia dituntut bisa mengimbangi dengan penyesuaian diri secara cepat dan tepat, termasuk memperkaya potensi dan kapabilitas yang tidak dapat dilakukan oleh teknologi AI saat ini (Fauzan, 2020). Dalam bidang layanan keuangan, bukti nyata bahwa SDM telah tergantikan oleh mesin adalah maraknya mesin tarik tunai ATM hingga ke daerah pelosok, yang justru saat ini semakin berkembang lagi dengan kemudahan akses melalui aplikasi internet banking atau e-banking dalam ponsel pintar. Hampir seluruh perusahaan perbankan telah menghadirkan fasilitas e-banking yang cukup diakses dalam genggaman tangan, sehingga konsumen tidak perlu datang ke bank. Adapun contoh lain adalah kemudahan pemesanan berbagai layanan jika seseorang ingin travelling atau staycation di hotel, di mana tiket perjalanan, pemesanan hotel, dan kebutuhan lainnya cukup dilakukan dilakukan di smartphone saja tanpa harus mencari layanan agen travel (Merlina \& Nuraini, 2020).

Karakteristik lain dari era Revolusi Indusri 4.0 adalah kecepatan akses informasi, tidak terkecuali informasi yang berkaitan dengan bisnis akuntansi yang selalu terbaru dan bersifat real-time. Revolusi industri ini dalam dunia bisnis juga mengakibatkan perubahan peran seorang akuntan. Pembukuan dapat dilakukan 
secara otomatis melalui software dengan hasil yang lebih akurat, lengkap, dan lebih cepat daripada melakukan pembukuan manual. Perusahaan dan pelaku usaha saat ini telah menggunakan software akuntansi seperti Omega Accounting, MyOB, Accurate Accounting, Microsoft Office Accounting Express (MOAE), dan lainlain. Software ini selain memberikan kemudahan kepada seorang akuntan, software ini juga memberikan akses kepada orang yang bahkan tidak memiliki dasar sebagai seorang akuntan untuk bisa melakukan pembukuan, dengan syarat pengguna memahami bagaimana cara kerja software akuntansi tersebut, (Merlina \& Nuraini, 2020). Sistem otomasi ini akan menciptakan kesenjangan keterampilan dan kompetensi untuk pekerjaan akuntansi/keuangan, (Suarta et al., 2020). Hal ini tentu saja sangat membahayakan peran akuntan dalam dunia bisnis.

Perkembangan teknologi dalam beberapa tahun ditakutkan akan mampu menggantikan peran profesi akuntan. Profesi akuntan yang harus mengikuti irama dari revolusi industry. Alih - alih tergerus atau mampu bertahan terhadap perubahan tersebut, sehingga akuntan akan dihadapkan pada posisi Signal admit to noise, Changes takes hold, The inevitable transformation, Adapting to the new normal (Iswanto \& Wahjono, 2019). Maka dari itu seorang akuntan agar mampu bersaing dalam dunia kerja perlu memiliki sertifikasi khusus selain dalam bidang akuntansi juga dalam bidang lain misalnya dalam bidang teknologi. Untuk kebutuhan industri saat ini, akuntan tidak hanya cukup bermodalkan skill accounting yang baik, namun wajib memiliki kemampuan interpersonal dan intrapersonal yang handal, Selain itu, pemahaman bisnis yang baik dan kemampuan teknis akan sangat diperlukan agar mampu bersaing di era industri saat ini (Rosmida, 2019).

Kondisi saat ini menuntut generasi yang akan memasuki dunia kerja agar mampu menempatkan diri secara strategis di tengah persaingan karir, tidak terkecuali sarjana akuntansi (Latifah et al., 2020). Di era 4.0 ini, keberadaan keterampilan interpersonal semakin dibutuhkan seiring dengan tuntutan untuk perubahan karena teknologi digital yang besar dalam pekerjaan akuntan (Ghofirin \& Primasari, 2021). Tantangan tidak hanya muncul dari banyaknya jumlah SDM, namun juga dari penggunaan mesin yang mulai mengambil alih peran manusia dalam pekerjaan. Agar dapat menghadapi segala perubahan yang akan muncul, beberapa kemampuan menjadi sangat vital untuk dimiliki, seperti problem-solving, critical thinking, analytical thinking, kreatifitas, hingga kemampuan bekerjasama (Fauzan, 2020). Selain soft skill, pengetahuan teknologi informasi juga sangat diperlukan dalam menghadapi persaingan dunia kerja. Perusahaan yang sudah menerapkan teknologi informasi yang terkomputerisasi dan terintegrasi dan didukung oleh aplikasi pendukung biasanya memberikan dampak positif bagi kelangsungan kinerja perusahaan karena mampu menghasilkan laporan keuangan yang tepat waktu, akurat, dan dapat dipercaya sehingga banyak perusahaan memerlukan tenaga akuntansi yang handal dalam penggunaan teknologi informasi (Ratnaningsih \& Suaryana, 2014). Isu tersebut menjadi research background bagi studi ini untuk menyajikan sebuah kajian empiris tentang bagaimana persepsi kesiapan mahasiswa akuntansi dalam menghadapi tantangan era revolusi industri 4.0 berdasarkan aspek pemahaman akuntansi, soft skill dan pengetahuan teknologi informasi. Aspek-aspek tersebut dinyatakan sebagai variabel independen yang berkontribusi terhadap persepsi kesiapan responden. 
Tujuan dari penelitian ini adalah untuk mengetahui pengaruh dari pemahaman akuntansi, soft skill, pengetahuan teknologi informasi, mahasiswa jurusan akuntansi terhadap kesiapan menghadapi tantangan era revolusi industri 4.0. Manfaat dalam penelitian ini adalah hasil penelitian diharapkan dapat digunakan sebagai sumber informasi dan bahan pertimbangan dalam pengambilan keputusan bagi pihak terkait, khususnya kepada pihak pengelola perguruan tinggi dan mahasiswa untuk mengetahui hal-hal apa saja yang dapat diantisipasi atau lebih difokuskan dalam meningkatkan kesiapan calon mahasiswa akuntansi dalam menghadapi tantangan di revolusi industri ini, seperti meningkatkan kualitas sumber daya manusia dalam upaya menghadapai era revolusi industri 4.0 antara lain dengan meningkatkan pemahaman akuntansi, soft skill dan meningkatkan pengetahuan teknologi informasi. Hal ini bisa dimaksimalkan apabila pihak pengelola universitas melakukan berbagai pelatihan ataupun sertifikasi bagi mahasiswa jurusan akuntansi dalam bidang pelatihan akuntansi, teknologi informasi serta pengembangan soft skill.

World Economic Forum (2015) menyatakan bahwa dalam era revolusi industry 4.0 seorang akuntan harus menguasai tiga pilar penting antara lain literasi, kompetensi dan karakter. Sejalan dengan prinsip resources based view theory oleh (Wernerfelt, 1984) dan disempurnakan oleh (Barney, 1991) yang menyatakan bahwa untuk mencapai keunggulan kompetitif yang memiliki orientasi jangka panjang maka perusahaan harus menggunakan dan memaksimalkan sumber daya internal perusahaan (Stuart, 1995). Sumber daya internal perusahaan yang kompetitif dapat didapatkan dengan merekrut tenaga kerja yang profesional dengan karakteristik dan dapat menciptakan nilai tambah bagi perusahaan, kreatif, unik, tidak dapat digantikan (Wernerfelt, 1984) dan (Barney, 1991).

Semakin baik pemahaman akuntansi seorang akuntan maka semakin baik pula kesiapan akuntan dalam menghadapi era revolusi industry 4.0. 54 persen lowongan membutuhkan prospektif karyawan yang memiliki pemahaman dalam akuntansi dasar, akuntansi biaya, akuntansi jasa (Dewi et al., 2020). Penelitian (Burhasan, 2016) yang berjudul Persepsi Mahasiswa Akuntansi Terhadap Kesiapan Menghadapi Tantangan ASEAN Economic Community 2015 menunjukkan bahwa variabel keilmuan akuntansi $\left(X_{1}\right)$ mempunyai hubungan yang positif signifikan terhadap kesiapan dalam menghadapi tantangan ASEAN Economic Community 2015. Penelitian (Latifah et al., 2020) menunjukkan hasil bahwa variabel keilmuan akuntansi menunjukkan pengaruh positif terhadap kesiapan dalam menghadapi tantangan era revolusi industri 4.0. Hasil penelitian lain menunjukkan pengaruh yang berbeda dari penelitian sebelumnya yakni variabel kompetensi sarjana akuntansi tidak berpengaruh terhadap kemampuan sarjana akuntansi dalam menghadapi era revolusi industri 4.0 (Puspitasari et al., 2019). Penelitian (Saraswati et al., 2020) menunjukkan bahwa kompetensi etika, kompetensi pengetahuan, kompetensi kemampuan, kompetensi hubungan, kompetensi analitis, dan Locus of control memiliki efek positif pada kesiapan siswa jurusan akuntansi dalam menghubungkan dunia kerja era revolusi industri 4.0.

$\mathrm{H}_{1}$ : Pemahaman akuntansi berkontribusi positif signifikan terhadap kesiapan mahasiswa akuntansi. 
Penguatan Pendidikan Karakter memiliki kontribusi yang signifikan terhadap cita-cita pendidikan nasional sebagai bentuk investasi pendidikan dalam menciptakan generasi emas di era global dengan membangun keseimbangan hard skill dan soft skill (Taufik, 2020). Hard skill yang dibarengi dengan soft skill yang baik mampu memberikan nilai lebih khususnya bagi seorang akuntan. Tanpa soft skill yang lebih baik, sangat sulit agar akuntan masa depan dipekerjakan (Jaafar, 2018). Semakin baik soft skill seorang akuntan maka kesiapan dalam menghadapi era revolusi industry 4.0 juga semakin baik. Pernyataan ini didukung oleh penelitian yang dilakukan oleh (Burhasan, 2016) juga menunjukkan bahwa variabel Soft skill $\left(\mathrm{X}_{2}\right)$ mempunyai hubungan yang positif signifikan terhadap kesiapan dalam menghadapi tantangan ASEAN Economic Community 2015. Kemampuan kerja akuntan yang lebih tinggi terkait dengan soft skill yang lebih baik dapat meningkatkan persepsi publik tentang bidang akuntansi. Penelitian (Teng et al., 2019) menunjukkan bahwa kurikulum universitas membantu mengembangkan soft skill siswa dan mendukung hubungan antara soft skill dan kesiapan siswa untuk pekerjaan. Hasil penelitian lain menunjukkan pengaruh yang berbeda yakni hard skill dan motif sosial berpengaruh signifikan terhadap kesiapan kerja, sementara soft skill tidak berpengaruh signifikan terhadap kesiapan kerja dalam era revolusi industry 4.0 (Bhadraswara \& Iqbal, 2020).

$\mathrm{H}_{2}$ : Soft skill berkontribusi positif signifikan terhadap kesiapan mahasiswa akuntansi.

Perguruan tinggi perlu menerapkan hal-hal seperti memperbanyak pelatihan dan sertifikasi tentang pengetahuan TI (Steelyana W, 2012). Semakin tinggi pengetahuan teknologi informasi $\left(X_{3}\right)$ maka semakin tinggi pula kesiapan menghadapi tantangan era revolusi industri $4.0(\mathrm{Y})$. Penelitian yang dilakukan oleh (Latifah et al., 2020) menunjukkan hasil bahwa variabel teknologi informasi menunjukkan pengaruh positif terhadap kesiapan dalam menghadapi tantangan era revolusi industri 4.0. Penelitian yang dilakukan oleh (Yulianti \& Juita, 2021) menunjukkan hasil bahwa terdapat pengaruh positif signifikan variabel literasi digital terhadap kesiapan kerja calon akuntan di era disrupsi teknologi digital.

$\mathrm{H}_{3}$ : Pengetahuan teknologi informasi berkontribusi positif signifikan terhadap kesiapan mahasiswa akuntansi.

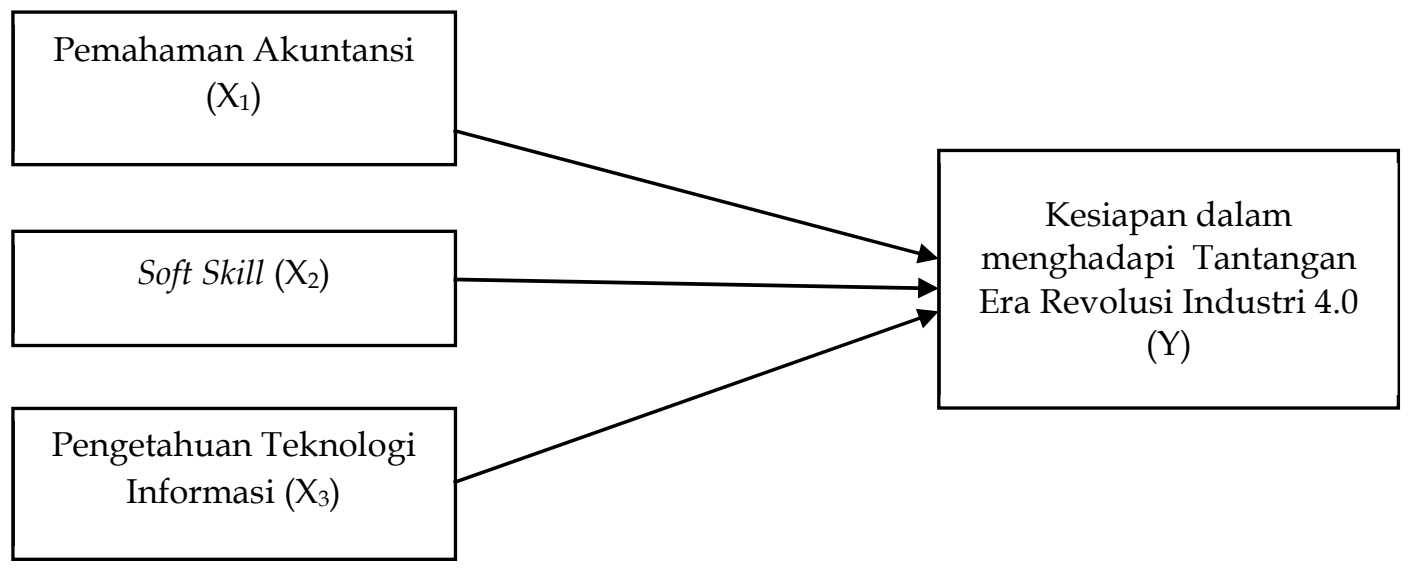

Sumber: Data Penelitian, 2021

Gambar 1. Model Penelitian 


\section{METODE PENELITIAN}

Studi ini mengambil tempat penelitian di Jurusan Akuntansi Politeknik Negeri Bali. Data yang diteliti adalah jenis data kualitatif yang dikuantitatifkan yang berasal dari sumber pertama (mahasiswa Jurusan Akuntansi), atau yang disebut sebagai data primer dengan menggunakan kuisioner. Data primer yang digunakan adalah kuesioner, yakni rangkaian item pertanyaan dengan skala likert. Jawaban responden yang diterima tersebut merupakan data penelitian yang akan digunakan untuk analisis data. Populasi riset adalah mahasiswa Jurusan Akuntansi Politeknik Negeri Bali, di mana sampel diambil dengan pertimbangan khusus. Teknik ini disebut sebagai purposive sampling (Sugiyono, 2018). Kriteria sampel meliputi; mahasiswa jurusan akuntansi dengan status aktif, serta mahasiswa prodi semester akhir pada prodi D3 Akuntansi dan D4 Akuntansi Manajerial yang pada saat penelitian ini dilakukan sedang atau telah menempuh Praktik Kerja Lapangan. Jumlah akhir responden yang diperoleh adalah 137 sampel.

Sebelum penelitian inti, instrumen terlebih dahulu diuji secara statistik untuk memastikan seluruh item telah valid dan reliable. Item dinyatakan valid jika nilai pearson ( $\mathrm{r}$ hitung) $>\mathrm{r}_{\text {tabel }}$ yang diperoleh dari tabel statistik, serta dinyatakan reliabel apabila nilai Cronbach Alpha > batas 0,6 (Ghozali, 2013). Mengingat konsep penelitian ini adalah sebab akibat di antara variabel, maka alat yang digunakan dalam menjawab hipotesis adalah regresi linier berganda. Menurut (Ghozali, 2013), secara umum regresi linear berganda dirumuskan sebagai berikut.

$Y=\alpha+\beta_{1} X_{1}+\beta_{2} X_{2}+\beta_{3} X_{3}+\varepsilon$.

Keterangan:

Y : Kesiapan dalam menghadapi tantangan era revolusi industri 4.0,

a : Konstanta

$\beta_{\mathrm{n}} \quad$ : Koefisiensi regresi

$\mathrm{X}_{1} \quad$ : Pemahaman akuntansi

$\mathrm{X}_{2} \quad$ : Soft skill

$\mathrm{X}_{3} \quad$ : Teknologi informasi

$\varepsilon \quad:$ Standar error (faktor pengganggu di luar model)

Pengujian hipotesis pada analisis regresi dilakukan dengan dua tahap yaitu menguji signifikansi model secara simultan dengan menggunakan ANOVA (analisis of variance) dan statistik uji F, lalu dilakukan pengujian hipotesis secara parsial dengan menggunakan statistic uji - t. Hasil analisis nantinya akan memperlihatkan seberapa besar/kuat pengaruh dari tiap prediktor terhadap variabel dependen, sekaligus apakah arahnya positif atau negative. Analisis pengaruh/efek di sini terdiri dari dua tahap, yakni efek peubah bebas secara simultan yang teridentifikasi dari uji F dan efek secara parsial ditinjau dari uji t.

Salah satu bentuk kesiapan seorang akuntan dalam menghadapi industry 4.0, selain bagaimana dia mampu menghasilkan laporan keuangan yang baik, adalah tentang bagaimana dia handal dalam menganalisis berbagai variabel dan memprosesnya dengan kritis dalam pengambilan keputusan. Kemampuan ini adalah hal yang tidak bisa dilakukan oleh mesin (Tikurante et al., 2020). Kesiapan dalam menghadapi era industri 4.0 diidentifikasi dengan beberapa indikator, yaitu pengetahuan tentang bagaimana era tersebut, manfaat, tantangan, 
ancaman revolusi industri 4.0, kesiapan dalam menguasai ilmu akuntansi, soft skill, dan teknologi informasi (Latifah et al., 2020).

Pemahaman akuntansi merepresentasikan kapabilitas responden dalam mengerti bidang akuntansi secara keseluruhan dan baik (Pasek, 2017). Indikator dari variabel pemahaman akuntansi mencakup kemampuan responden untuk tahu, paham, dan menguasai mata kuliah penting dalam jurusan akuntansi; teori akuntansi, akuntansi keuangan, sistem informasi akuntansi, pemeriksaan akuntansi, serta akuntansi perpajakan (Latifah et al., 2020). Selanjutnya, soft skills merupakan kemampuan yang terbentuk pada diri seseorang dan dapat dikembangkan serta sebagai pelengkap dari kemampuan hard skills (Abdullah, 2017). Indikator dari v a riabelsoft skill antara lain kemampuan berkomunikasi, kemampuan berpikir kritis dan memecahkan masalah, belajar dan mengelola informasi, etika, moral dan professional, kemampuan kepemimpinan (Rokhayati et al., 2017). Teknologi informasi merepresentasikan suatu alat pemrosesan data untuk diolah menjadi produk informasi yang penting untuk pengambilan keputusan. Contohnya adalah informasi akuntansi yang dapat membantu manajemen sebelum mengambil keputusan (Jawabreh \& Alrabei, 2012). Indikator dari variabel pengetahuan teknologi informasi meliputi kemampuan dalam pengoperasian komputer, menguasai penggunaan aplikasi Microsoft sesuai standar kerja, kemampuan menggunakan program-program akuntansi, keaktifan dalam kegiatan yang terkait teknologi informasi, keakraban dengan fasilitas e-commerce, serta kemampuan mengoperasikan alat komunikasi (Latifah et al., 2020).

\section{HASIL DAN PEMBAHASAN}

Responden dalam penelitian ini memiliki karakteristik antara lain dari 137 jumlah responden terdiri dari 90 orang atau sekitar 65,7 persen berjenis kelamin perempuan dan 47 orang atau sekitar 34,3 persen berjenis kelamin laki-laki, Responden dalam penelitian ini terdiri dari sebanyak 43 orang atau sekitar 31,4 persen berasal dari prodi D3 Akuntansi sedangkan 94 orang atau sekitar 68,6 persen berasal dari prodi D4 Akuntansi Manajerial.

Dalam uji instrumen, item kuesioner dinyatakan valid ketika skor pearson $\left(r_{\text {hitung }}\right)>$ skor $r_{\text {tabel }}$ yang diketahui dari tabel statistik. Kemudian, variabel dinyatakan reliabel apabila nilai Cronbach Alpha > batas 0,6. Berdasarkan pengolahan uji coba validitas, seluruh butir pertanyaan tiap variabel, yaitu pemahaman akuntansi $\left(\mathrm{X}_{1}\right)$, soft skill $\left(\mathrm{X}_{2}\right)$, pengetahuan teknologi informasi $\left(\mathrm{X}_{3}\right)$, dan kesiapan menghadapi tantangan era revolusi industri 4.0 (Y) secara keseluruhan memperoleh skor $r_{\text {hitung }}>r_{\text {tabel }}$ 0,361. Artinya, seluruh butir pertanyaan dianggap valid. Selanjutnya, gabungan seluruh item dari tiap variabel memperoleh skor Cronbach Alpha lebih > batas 0,600, sehingga dinyatakan memenuhi syarat reliabilitas dan layak sebagai instrumen pengumpulan data.

Proses berikutnya yaitu penguji hipotesis, yang terlebih dahulu harus diawali dengan uji prasyarat. Analisis Regresi dalam studi ini menggunakan prasyarat normalitas, heteroskedastisitas, dan multikolinearitas. Uji normalitas dilakukan untuk memastikan tidak ada residual (variabel pengganggu) dalam model regresi, baik berdasarkan metode grafik normal P-P Plot maupun uji Kolmogorov-Smirnov. Gambar 2, menampilkan hasil dalam bentuk grafik, 
sedangkan Tabel 1, menampilkan hasil dengan metode Kolmogorov-Smirnov dalam bentuk tabel.

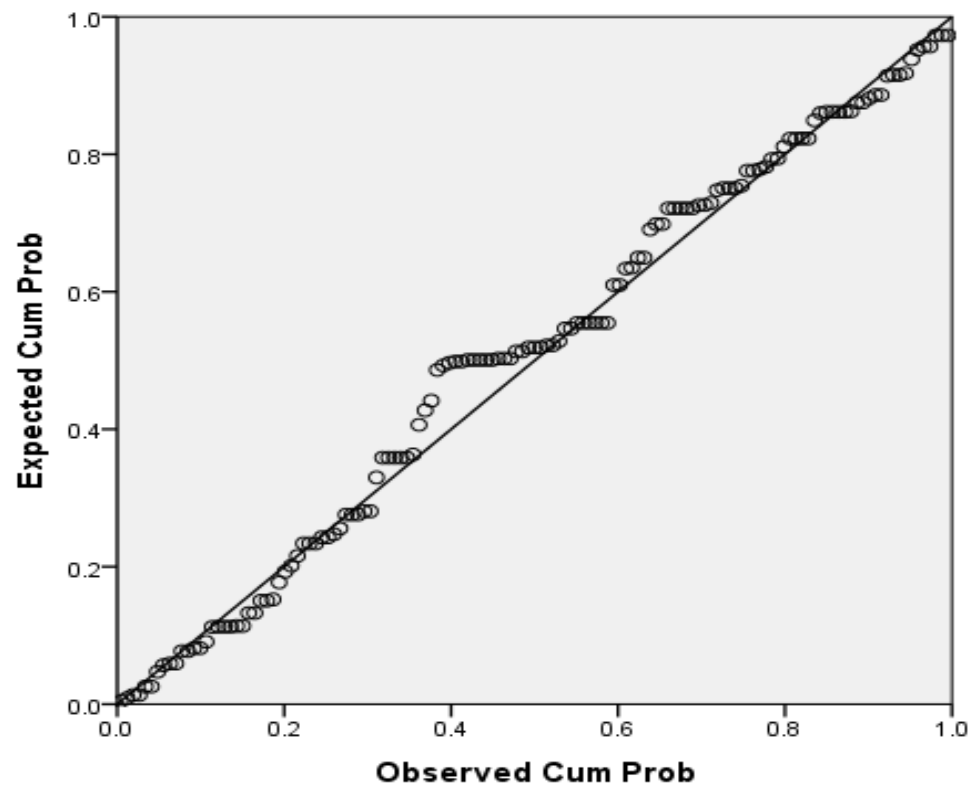

Gambar 2. Grafik P-P Plot Normalitas data

Sumber: Data Penelitian, 2021

Gambar 2, menampilkan sebaran titik-titik plot yang secara umum mendekati garis diagonal. Dengan kata lain, residual mengikuti memiliki sebaran normal. Kemudian, hasil pengujian asumsi dalam bentuk angka yaitu sebagai berikut.

Tabel 1. Normalitas Data berdasarkan metode Kolmogorov-Smirnov

\begin{tabular}{lll}
\hline & & Unstandardized \\
& & Residual \\
\hline $\mathrm{N}$ & Mean & 137 \\
Normal Parameters ${ }^{a, \mathrm{~b}}$ & Std, Deviation & 0,0000000 \\
& Absolute & 1,98448911 \\
Most Extreme Differences & Positive & 0,107 \\
& Negative & 0,042 \\
Kolmogorov-Smirnov Z & & $-0,107$ \\
Asymp, Sig, (2-tailed) & & 1,247 \\
\hline Simber: Data Pene & 0,089 \\
\hline
\end{tabular}

Sumber: Data Penelitian, 2021

Nilai signifikansi ( $p$ ) uji Kolmogorov-Smirnov yaitu 0,089, atau > taraf nyata 0,05. Angka ini memperlihatkan bahwa residual mengikuti distribusi normal. Dengan demikian, uji asumsi normalitas dengan kedua metode tersebut menunjukkan bahwa data penelitian memiliki distribusi normal (asumsi terpenuhi).

Uji prasyarat selanjutnya adalah heteroskedasitas, yaitu untuk memastikan ketidaksamaan variance dari residual antar pengamatan. Dalam sebuah model yang bagus, residual dapat dipastikan tidak memiliki kesamaan (homoskedasitas). Hasil dinyatakan lolos uji asumsi klasik ini apabila nilai signifikan $t>0,05$ (Ghozali, 2013). Dalam studi ini, pengujian dilakukan dengan 2 metode, yaitu grafik Scatterplot dan uji Glejser. 


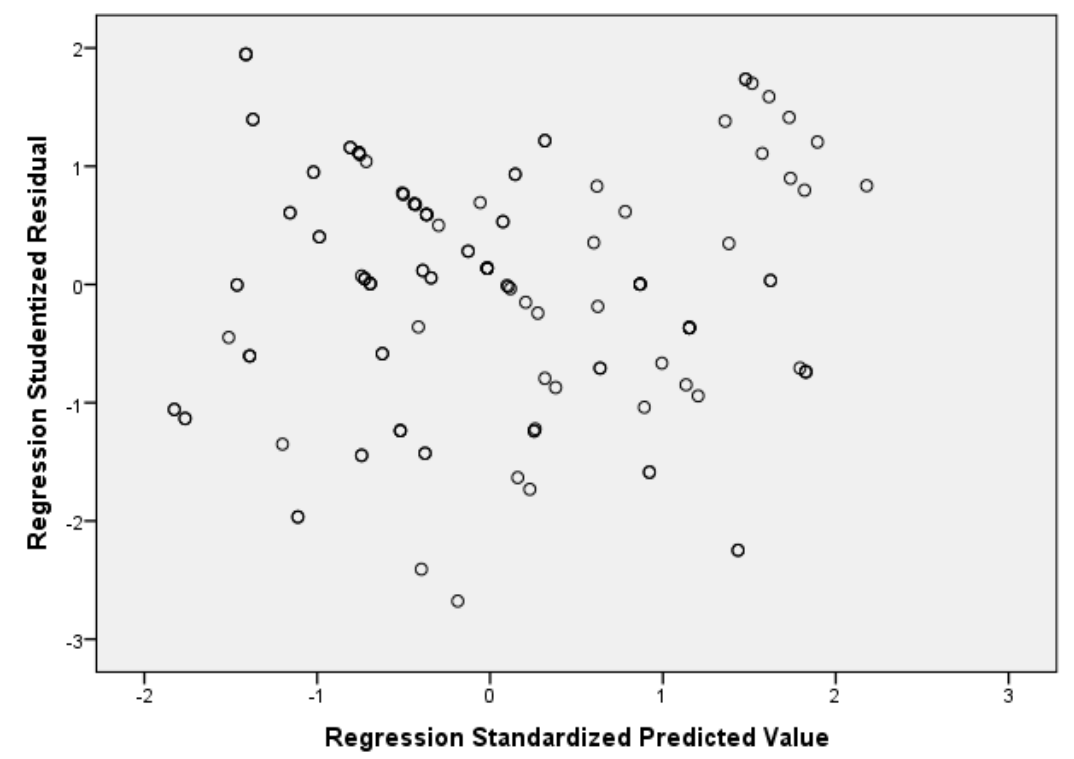

\section{Gambar 3. Uji Heteroskedastisitas dengan Menggunakan Grafik Scatter Plot ZPRED dan SRESID}

Sumber: Data Penelitian, 2021

Hasil uji Gambar 3, memperlihatkan titik-titik plot yang tersebar secara random dan tidak membentuk pola. Selanjutnya, hasil ini dikuatkan dengan perolehan uji dengan Glejser adalah sebagai berikut.

Tabel 2. Heteroskedastisitas data berdasarkan metode Glejser

\begin{tabular}{llcc}
\hline \multicolumn{1}{c}{ Model } & $\mathrm{t}$ & \multicolumn{1}{c}{ Sig, } \\
\hline \multirow{4}{*}{1} & (Constant) & 1,730 & 0,086 \\
& Pemahaman Akuntansi & $-1,969$ & 0,051 \\
& Soft skill & 1,552 & 0,123 \\
& Pengetahuan Teknologi Informasi &,- 259 & 0,796 \\
\hline
\end{tabular}
Sumber: Data Penelitian, 2021

Tabel 2, menampilkan hasil uji Glejser dengan perolehan $p$-value variabel pemahaman akuntansi $\left(X_{1}\right)$, soft skill $\left(X_{2}\right)$ sebesa, dan pengetahuan teknologi informasi $\left(X_{3}\right)$ masing-masing yaitu $0,051,0,123$, dan 0,796 . Secara umum, hasil uji asumsi heteroskedastisitas dengan kedua metode tersebut mengindikasikan model regresi yang baik (asumsi terpenuhi).

Terakhir, uji asumsi multikolinieritas dilakukan untuk memastikan tidak adanya keterkaitan antar peubah bebas. Dalam studi ini, uji asumsi diinterpretasikan dari nilai tolerance dan VIF, yang dinyatakan bebas multikolinearitas bilamana nilai tolerance $>0,1$. Atau, dapat pula diinterpretasikan dari skor VIF < 10 (Ghozali, 2013).

Tabel 3. Uji Multikolinieritas dengan Menggunakan Uji VIF

\begin{tabular}{lcc}
\multicolumn{1}{c}{ Model } & \multicolumn{2}{c}{ Collinearity Statistics } \\
& Tolerance & VIF \\
\hline Pemahaman Akuntansi & 0,651 & 1,537 \\
Soft skill & 0,509 & 1,963 \\
Pengetahuan Teknologi Informasi & 0,538 & 1,859 \\
\hline
\end{tabular}

Sumber: Data Penelitian, 2021 
Tabel 3, menampilkan perolehan nilai VIF pada variabel pemahaman akuntansi $\left(\mathrm{X}_{1}\right)$, soft skill $\left(\mathrm{X}_{2}\right)$, dan pengetahuan teknologi informasi $\left(\mathrm{X}_{3}\right)$ masingmasing adalah 1,537, 1,963, dan 1,859 (<10). Nilai tersebut menunjukkan model regresi yang baik (asumsi terpenuhi). Pada tahap ini, telah diketahui bahwa asumsi klasi secara keseluruhan telah lolos/terpenuhi, sehingga uji hipotesis dengan metode regresi linier dapat dilakukan. Analisis ini akan menggambarkan pengaruh antar variabel, baik secara simultan maupun parsial. Tabel 4, menyajikan hasil analisis regresi terkait pengaruh pemahaman akuntansi $\left(X_{1}\right)$, soft skill $\left(\mathrm{X}_{2}\right)$, dan pengetahuan teknologi informasi $\left(\mathrm{X}_{3}\right)$ terhadap kesiapan menghadapi era revolusi industri $4.0(\mathrm{Y})$.

Tabel 4. Hasil Regresi Linier Berganda

\begin{tabular}{|c|c|c|c|c|c|c|}
\hline \multirow{2}{*}{\multicolumn{2}{|c|}{ Model }} & \multicolumn{2}{|c|}{$\begin{array}{l}\text { Unstandardized } \\
\text { Coefficients }\end{array}$} & \multirow{2}{*}{$\begin{array}{l}\text { Standardized } \\
\text { Coefficients } \\
\text { Beta }\end{array}$} & \multirow[t]{2}{*}{$\mathrm{t}$} & \multirow[t]{2}{*}{ Sig. } \\
\hline & & $B$ & Std, Error & & & \\
\hline \multirow{4}{*}{1} & (Constant) & $-0,235$ & 2,087 & & $-0,113$ & 0,910 \\
\hline & Pemahaman Akuntansi & 0,124 & 0,058 & 0,139 & 2,120 & 0,036 \\
\hline & Soft skill & 0,180 & 0,059 & 0,225 & 3,035 & 0,003 \\
\hline & $\begin{array}{l}\text { Pengetahuan } \\
\text { Informasi }\end{array}$ & 0,476 & 0,064 & 0,535 & 7,402 & 0,000 \\
\hline
\end{tabular}

Sumber: Data Penelitian, 2021

Poin pertama yang dibahas dalam hasil analisis regresi dalam studi ini adalah persamaan. Dilihat dari Tabel 4, sehingga terrumuskan sebuah persamaan yaitu sebagai berikut.

$$
\mathrm{Y}=-0,235+0,124 \mathrm{X} 1+0,180 \mathrm{X} 2+0,476 \mathrm{X} 3+\varepsilon
$$

Nilai koefisien pemahaman akuntansi $\left(X_{1}\right)$ sebesar 0,124 menunjukkan adanya pengaruh positif antara $\mathrm{X}_{1}$ terhadap $\mathrm{Y}$. Artinya, setiap peningkatan nilai pemahaman akuntansi $\left(\mathrm{X}_{1}\right)$ akan berpengaruh terhadap peningkatan nilai prediksi Y. Semakin tinggi pemahaman akuntansi $\left(X_{1}\right)$, maka semakin tinggi kesiapan menghadapi tantangan era revolusi industri $4.0(\mathrm{Y})$. Nilai koefisien soft skill $\left(\mathrm{X}_{2}\right)$ sebesar 0,180 menunjukkan adanya pengaruh positif antara peubah $\mathrm{X}_{2}$ terhadap $\mathrm{Y}$. Artinya, setiap peningkatan nilai $\mathrm{X}_{2}$ akan berpengaruh terhadap peningkatan nilai prediksi $Y$. Dengan kata lain, tingginya $\mathrm{X}_{2}$ akan linier dengan tingginya $\mathrm{Y}$. Koefisien pengetahuan teknologi informasi $\left(X_{3}\right)$ sebesar 0,476 menunjukkan adanya pengaruh positif antara $\mathrm{X}_{3}$ terhadap $\mathrm{Y}$. Artinya, setiap peningkatan nilai peubah $X_{3}$ akan berpengaruh terhadap peningkatan nilai prediksi $Y$. Berarti, semakin tingginya $X_{3}$ akan linier dengan semakin tingginya $Y$.

Bagian selanjutnya adalah membahas pengujian hipotesis, yakni melalui hasil uji F yang menjelaskan pengaruh secara simultan, dan uji t yang menjelaskan pengaruh secara parsial. Selain keduanya, penting untuk diketahui besar efek seluruh peubah bebas terhadap peubah terikat yang tercermin dari skor $\mathrm{R}$ (koefisien determinasi). Fokus pengkajian dalam studi ini adalah pada variabel bebas pemahaman akuntansi $\left(\mathrm{X}_{1}\right)$, soft skill $\left(\mathrm{X}_{2}\right)$, dan pengetahuan teknologi informasi $\left(X_{3}\right)$, kaitannya dengan pembentukan persepsi kesiapan mahasiswa akuntansi dalam menghadapi tantangan era revolusi industri 4.0 (Y). Tabel 5, menunjukkan hasil uji $\mathrm{F}$, di mana dapat diketahui perolehan satu angka yang menunjukkan nilai $F_{\text {hitung }}$ dan satu angka yang menunjukkan nilai signifikansi atau p-value, Pengambilan keputusan didasarkan pada batas taraf nyata 0,05 (5 persen). 
Tabel 5. Hasil Uji Simultan

\begin{tabular}{lllllll}
\hline Model & & Sum of Squares & $d f$ & Mean Square & $F$ & Sig. \\
\hline \multirow{2}{*}{1} & Regression & 896,931 & 3 & 298,977 & 74,243 & $0,000^{\mathrm{b}}$ \\
& Residual & 535,595 & 133 & 4,027 & & \\
& Total & 1432,526 & 136 & & & \\
\hline
\end{tabular}

Sumber: Data Penelitian, 2021

Uji simultan menunjukkan perolehan nilai sig $(0,000)<$ alpha $(0,050)$. Nilai tersebut mengindikasikan adanya pengaruh signifikan secara simultan antara pemahaman akuntansi $\left(X_{1}\right)$, soft skill $\left(X_{2}\right)$, dan pengetahuan teknologi informasi $\left(X_{3}\right)$ terhadap kesiapan mahasiswa akuntansi menghadapi tantangan era revolusi industri 4,0. Temuan ini searah dengan studi terdahulu yang menggambarkan pengaruh signifikan dan positif antara keilmuan akuntansi, skill bahasa Internasional dan pemahaman IT terhadap kesiapan responden dalam menghadapi tantangan era industry 4.0 (Latifah et al., 2020).

Salah satu hasil dari analisis regresi adalah koefisien determinasi (R), yakni nilai yang menggambarkan besar kontribusi peubah bebas terhadap peubah terikat. Interpretasi dilakukan dengan merubah bilangan dalam bentuk persen, di mana semakin tinggi persentasenya, maka besar pengaruh disebut semakin besar. Hasil dijelaskan sebagai berikut.

Tabel 6. Hasil Koefisien Determinasi

\begin{tabular}{lllll}
\hline Model & $\mathrm{R}$ & $\mathrm{R}$ Square & Adjusted R Square & Std. Error of the Estimate \\
\hline 1 & $0,791^{\mathrm{a}}$ & 0,626 & 0,618 & 2,0067 \\
\hline
\end{tabular}

Sumber: Data Penelitian, 2021

Perolehan nilai Adjusted $R$ Square 0,618 merepresentasikan besar pengaruh seluruh variabel bebas (pemahaman akuntansi, soft skill, dan pengetahuan TI) terhadap kesiapan mahasiswa akuntansi yaitu 61,8 persen dan sisanya sebesar 38,2 persen dipengaruhi oleh variabel lain diluar penelitian. Angka tersebut menandakan pentingnya mahasiswa untuk mempersiapkan diri dengan meningkatkan kemampuan dalam ketiga aspek tersebut.

Pengaruh antara pemahaman akuntansi $\left(X_{1}\right)$, soft skill $\left(X_{2}\right)$, dan pengetahuan teknologi informasi $\left(X_{3}\right)$ terhadap kesiapan mahasiswa akuntansi dapat diketahui dari sajian hasil analisis regresi yang terakhir, yaitu uji t (pada Tabel 7).

Tabel 7. Hasil Uji Parsial

\begin{tabular}{llcc}
\hline \multicolumn{1}{c}{ Model } & $\mathrm{t}$ & Sig. \\
\hline \multirow{3}{*}{1} & (Constant) & $-0,113$ & 0,910 \\
& Pemahaman Akuntansi & 2,120 & 0,036 \\
& Soft skill & 3,035 & 0,003 \\
& Pengetahuan Teknologi Informasi & 7,402 & 0,000 \\
\hline
\end{tabular}

Sumber: Data Penelitian, 2021

Uji parsial antara $X_{1}$ terhadap $Y$ menunjukkan perolehan nilai $t_{\text {hitung }}(2,120)>$ $t_{\text {tabel }}(1,978)$, dengan p-value $(0,036)<$ alpha $(0,050)$. Hasil ini memperlihatkan bahwa pemahaman akuntansi berpengaruh positif signifikan terhadap kesiapan mahasiswa akuntansi. Pemahaman akuntansi didefinisikan sebagai "bidang ilmu science, dalam akuntansi ada teori praktik akuntansi yang tidak hanya didasarkan pada kebiasaan tetapi juga didasarkan oleh teori akuntansi yang para akuntan gunakan sebagai pedoman untuk mempertahankan kelayakan dan keandalan informasi keuangan yang dihasilkan (Latifah et al., 2020). Pemahaman akuntansi 
merupakan kompetensi utama yang tidak bisa dimiliki oleh komputer atau perangkat lain yang memiliki kemampuan menganalisis suatu transaksi ekonomi yang rumit. Semakin baik pemahaman akuntansi yang dimiliki seorang akuntan maka kesiapan dalam menghadapi era revolusi industry 4.0 juga semakin baik. Ini sejalan dengan studi terdahulu yang menjelaskan pengaruh positif yang kuat antara keilmuan akuntansi terhadap siap tidaknya responden dalam memasuki era industry 4.0 (Latifah et al., 2020). Penelitian lain juga menyatakan bahwa variabel keilmuan akuntansi $\left(\mathrm{X}_{2}\right)$ sangat menentukan kesiapan generasi dalam bersaing dalam era masyarakat ekonomi ASEAN 2015.

Uji parsial antara $\mathrm{X}_{2}$ terhadap $\mathrm{Y}$ menunjukkan perolehan nilai $\mathrm{t}_{\text {hitung }}(3,036)>$ $t_{\text {tabel }}(1,978)$, dengan $p$-value $(0,003)<$ alpha $(0,050)$. Hasil ini menunjukkan bahwa soft skill berpengaruh positif signifikan terhadap kesiapan menghadapi mahasiswa akuntansi. Soft skills merupakan kemampuan yang terbentuk pada diri seseorang dan dapat dikembangkan serta sebagai pelengkap dari kemampuan hard skills (Abdullah, 2017). Hard skill ditambah dengan soft skill yang baik akan memberikan kontribusi lebih bagi seorang akuntan. Seorang calon akuntan dengan kompetensi akademik yang baik banyak ditemukan diberbagai perguruan tinggi, namun seorang calon akuntan dengan kompetensi akademik yang baik dan soft skill yang baik akan menjadi incaran dunia industry. Semakin baik soft skill seorang akuntansi maka kesiapan dalam menghadapi era revolusi industry 4.0 juga semakin baik. Temuan ini linier dengan teori yang menjelaskan pentingnya kontribusi soft skill dalam menguatkan daya saing lulusan terbaru di tengah persaingan ketat era industri 4.0 (Fauzan, 2020). Selain itu, soft skill juga terbukti sangat menentukan kesiapan generasi dalam bersaing dalam era masyarakat ekonomi ASEAN 2015 (Burhasan, 2016).

Uji parsial antara $\mathrm{X}_{3}$ terhadap $\mathrm{Y}$ menunjukkan perolehan nilai $\mathrm{t}_{\text {hitung }}(7,402)>$ $t_{\text {tabel }}(1,978)$ atau $p$-value $(0,000)<$ alpha $(0,050)$. Hasil secara nyata membuktikan bahwa pengetahuan teknologi informasi berpengaruh positif signifikan terhadap kesiapan menghadapi mahasiswa akuntansi. Teknologi informasi digunakan untuk mengubah data menjadi suatu informasi yang bermanfaat bagi pengambil keputusan. Contohnya adalah informasi akuntansi yang dapat membantu manajemen sebelum mengambil keputusan (Jawabreh \& Alrabei, 2012). Informasi akuntansi yang digunakan untuk pengambilan keputusan perusahaan dihasilkan melalui teknologi informasi. Seorang akuntan wajib memahami bagaimana cara kerja dan mampu mengoperasikan system dari hasil teknologi informasi. Pengetahuan teknologi informasi di era revolusi industry atau era digitalisasi dimana semua informasi harus bisa dihasilkan secara cepat dan akurat membuat kebutuhan tenaga yang paham akan teknologi informasi semakin dicari oleh dunia industry. Semakin tinggi pengetahuan teknologi informasi $\left(X_{3}\right)$ maka semakin tinggi pula kesiapan menghadapi tantangan era revolusi industri $4.0(\mathrm{Y})$. Hasil ini linier dengan temuan studi terdahulu yang menggambarkan arah pengaruh yang positif serta kontribusi yang signifikan antara pemahaman IT terhadap siap tidaknya sarjana dalam bersaing di era industri 4.0 (Latifah et al., 2020).

Penelitian yang dilakukan oleh (Yulianti \& Juita, 2021) menunjukkan hasil bahwa secara parsial terdapat pengaruh positif signifikan keahlian akuntansi, literasi digital dan literasi manusia terhadap kesiapan kerja calon akuntan di era 
disrupsi teknologi digital. Hasil penelitian secara simultan juga didukung oleh penelitian lain yang dilakukan sebelumnya. Penelitian (Yulianti \& Juita, 2021) menunjukkan hasil bahwa secara simultan terdapat pengaruh positif signifikan keahlian akuntansi, literasi digital dan literasi manusia terhadap kesiapan kerja calon akuntan di era disrupsi teknologi digital.

\section{SIMPULAN}

Studi ini membuktikan bahwa variabel pemahaman akuntansi $\left(\mathrm{X}_{1}\right)$, soft skill $\left(\mathrm{X}_{2}\right)$, dan pengetahuan teknologi informasi $\left(X_{3}\right)$ berkontribusi positif signifikan terkait siap tidaknya mahasiswa akuntansi menghadapi era revolusi industri $4.0(\mathrm{Y})$. Pemahaman akuntansi memiliki pengaruh yang positif terhadap kesiapan dalam menghadapi era revolusi industry 4.0, yang artinya semakin baik tingkat pemahaman akuntansi seorang calon akuntan maka semakin baik pula kesiapan dalam menghadapi era revolusi industry 4.0. Soft skill memiliki pengaruh positif terhadap kesiapan dalam menghadapi era revolusi industry 4.0, hal ini menunjukkan meningkatnya soft skill seorang akuntan diiringi juga oleh meningkatnya kesiapan dalam menghadapi era revolusi industry 4.0. Pengetahuan Teknologi Informasi memilik pengaruh yang positif terhadap kesiapan dalam menghadapi era revolusi industry 4.0. Di era revolusi industry yang mempunyai kebutuhan informasi yang cepat, pengetahuan teknologi informasi terutama dalam bidang bisnis sangat diperlukan sehingga seorang akuntan yang memiliki pengetahuan teknologi informasi yang baik adalah seorang akuntan yang memiliki kesiapan yang semakin baik dalam menghadapi era revolusi industry 4.0.

Dengan gambaran tersebut, maka pendidikan tinggi, khususnya Jurusan Akuntansi, disarankan untuk mengembangkan kurikulum ataupun metode pembelajaran sesuai dengan yang diperlukan dunia kerja saat ini dan bagi Mahasiswa Jurusan Akuntansi agar lebih tanggap dalam segala perubahan yang ada saat ini dan mampu beradaptasi akan perubahan termasuk memperbaharui keilmuan dengan mengikuti pelatihan atau sertifikasi yang bisa membantu dalam menghadapi persaingan dalam era revolusi 4.0.

Keterbatasan pada penelitian ini hanya mencakup beberapa variabel sedangkan kesiapan menghadapi era revolusi industry 4.0 difaktori oleh berbagai kondisi dan variabel lainnya. Sehingga penelitian selanjutnya dapat meneliti faktor atau variabel lain yang bisa berpengaruh seperti faktor eksternal karene penelitian ini hanya memfokuskan pada variabel dari faktor internal seorang akuntan. Hal ini penting dilakukan untuk memfasilitasi berbagai perkembangan yang muncul sehingga bisa mempengaruhi kesiapan dalam menghadapi era revolusi industry 4.0 .

\section{REFERENSI}

Abdullah, A. (2017). Pengembangan Pembelajaran Karakter Berbasis Soft skill di $\begin{array}{llll}\text { Perguruan Tinggi. } & \text { Ishraqi, } & 18-30 .\end{array}$ http://journals.ums.ac.id/index.php/ishraqi/article/view/2926/2300

Barney, J. (1991). Firm Resources and Sustained Competitive Advantage. Journal of Management, 17(1), 99-120.

Bhadraswara, B., \& Iqbal, S. (2020). The Influence Of Hard Skill, Soft skill, And Social Motive On The Work Readiness Of Accounting Students Of 
Universitas Brawijaya In The Industrial Revolution 4.0 Era. Jurnal Ilmiah Mahasiswa Fakultas Ekonomi Dan Bisnis Universitas Brawijaya Universitas Brawijaya, $8(2)$.

https://jimfeb.ub.ac.id/index.php/jimfeb/article/view/6772

Burhasan, D. S. (2016). Persepsi Mahasiswa Akuntansi Fakultas Ekonomi Dan Bisnis Unila Terhadap Kesiapan Dalam Menghadapi Asean Economic Community 2015. The JournalofAccountingand Financ E, 21(2).

Dewi, L. G. K., Dewi, N. A. W. T., \& Herawati, N. T. (2020). Young Accountant's Skills on 4.0: Ready or Not? Proceedings of the 5th International Conference on Tourism, Economics, Accounting, Management and Social Science (TEAMS 2020), 158(Teams), 6-15. https://doi.org/10.2991/aebmr.k.201212.002

Fauzan, F. (2020). Pengaruh Soft skill Dan Locus of Control Terhadap Kesiapan Fresh Graduate Dalam Era Industri 4.0 (Studi Pada Prodi Manajemen Unihaz Bengkulu). Creative Research Management Journal, 2(2), 1. https://doi.org/10.32663/crmj.v2i2.1105

Ghofirin, M., \& Primasari, N. S. (2021). Readiness to Face Society 5.0 Era, What Interpersonal Skill Does an Accounting Student Have ?: An Evidence from Indonesia. Procedia Business and Financial Technology, 1(Iconbmt), 0-5. https://doi.org/10.47494/pbft.2021.1.9

Ghozali, I. (2013). Aplikasi Analisis Multivariate dengan menggunakan SPSS. In Gramedia.

Hart. L Stuart. (1995). Natural-Resource-Based View Of The Firm. The Academy Of Management Review, 20(4), 986-1014.

Iswanto, A. C., \& Wahjono. (2019). Pengaruh Revolusi Industri 4.0 Terhadap Ilmu Akuntansi. Jurnal Ilmiah INFOKAM, 1(1), 1-6.

Jaafar, S. B. (2018). Are Soft skills Required for Accounting Students in Future Careers? SSRN Electronic Journal.

Jawabreh, O. A., \& Alrabei, A. M. (2012). The Impact of Accounting Information System in Planning, Controlling and Decision-Making Processes in Jodhpur Hotels. Asian Journal of Finance $\mathcal{E}$ Accounting, 4(1). https://doi.org/10.5296/ajfa.v4i1.1435

Latifah, S. E., Junaidi, \& Kartika Sari, A. F. (2020). Persepsi Mahasiswa Akuntansi Tentang Keilmuan Akuntansi dan Soft skill (Bahasa Inggris dan Teknolosi Informasi) Terhadap Kesiapan Menghadapi Tantangan Era Revolusi Industri 4.0. E-Jra, 09(02), 47-57.

Merlina, M., \& Nuraini, A. (2020). Analisis Persepsi Dosen Akuntansi Dan Mahasiswa Akuntansi Mengenai Peranan Akuntan Di Era Revolusi Industri 4.0. JAS-PT (Jurnal Analisis Sistem Pendidikan Tinggi Indonesia), 4(2), 149. https://doi.org/10.36339/jaspt.v4i2.347

Pasek, N. S. (2017). Pengaruh Kecerdasan Intelektual Pada Pemahaman Akuntansi Dengan Kecerdasan Emosi Dan Kecerdasan Spiritual Sebagai Variabel Pemoderasi. Jurnal Ilmiah Akuntansi. https:// doi.org/10.23887/jia.v1i1.9983

Puspitasari, E., Askandar, N., \& Mawardi, M. C. (2019). Pengaruh Kompetensi Sarjana Akuntansi, Regulasi Pemerintah Dan Etika Profesi Terhadap Kemampuan Sarjana Akuntansi Untuk Bersaing Dalam Menghadapi Era Revolusi Industri 4.0. E-Jra, 08(01), 1-13.

Ratnaningsih, K. I., \& Suaryana, I. G. N. A. (2014). Pengaruh Kecanggihan 
Teknologi Informasi, Partisipasi Manajemen, Dan Pengetahuan Manajer Akuntansi Pada Efektivitas Sistem Informasi Akuntansi. E-Jurnal Akuntansi, 6(1), 1-16. https://ocs.unud.ac.id/index.php/Akuntansi/article/view/7775 Rokhayati, A., Kambara, R., \& Ibrahim, M. (2017). Pengaruh Soft skill dan Perencanaan Karir Terhadap Kinerja Karyawan dengan Kualitas Pelatihan Sebagai Variabel Modertor. Riset Bisnis Dan Manajement Tirtayasa, 1(2), 107125.

Rosmida, R. (2019). Transformasi Peran Akuntan dalam Era Revolusi Industri 4.0 dan Tantangan Era Society 5.0. Inovbiz: Jurnal Inovasi Bisnis, 7(2), 206. https://doi.org/10.35314/inovbiz.v7i2.1197

Saraswati, A. A. S. D., Putri, I. G. A. M. A. D., Suprasto, H. B., \& Sari, M. M. R. (2020). Influence of competence and locus of control on readiness of accounting department students facing the world of work era industrial revolution 4.0. International Research Journal of Management, IT E Social Science, 7(4), 14-23. https://sloap.org/journals/index.php/irjmis

Steelyana W, E. (2012). Preparing Indonesia Skilled Labor in the Field of Accounting, Finance and Capital Market for ASEAN Economic Community 2015.

Suarta, I. M., Suwintana, I. K., Sudhana, I. G. P. F. P., Kadek, N., \& Hariyanti, D. (2020). Persepsi Pendidik Vokasi Atas Atribut-Atribut Employability Skills Yang Dibutuhkan Dunia Kerja Era Revolusi Industri 4.0. Jurnal Vokasi Indonesia, 8(1), 1-11. https:/ / doi.org/10.7454/jvi.v8i1.150

Sugiyono. (2018). Metode Peneiltian Kuantitatif, Kualitatif dan R\&D. In Alfabeta Bandung.

Taufik, M. (2020). Strategic Role of Islamic Religious Education in Strengthening Character Education in the Era of Industrial Revolution 4.0. Jurnal Ilmiah Islam Futura, 20(1), 86. https:// doi.org/10.22373/jiif.v20i1.5797

Teng, W., Ma, C., Pahlevansharif, S., \& Turner, J. J. (2019). Graduate readiness for the employment market of the 4th industrial revolution: The development of soft employability skills. Education and Training, 61(5), 590-604. https://doi.org/10.1108/ET-07-2018-0154

Tikurante, R. U., Pasoloran, O., \& Sabandar, S. Y. (2020). Quo Vadis Akuntan Dalam Era Revolusi Industri 4.0. Paulus Journal of Accounting (PJA), 2(1), 1730.

Wernerfelt, B. (1984). A Resource-Based View of The Firm. Strategic Management Journal, 5(2), 171-180.

Yulianti, M., \& Juita, V. (2021). Pengaruh Keahlian Akuntansi, Literasi Digital dan Literasi Manusia Terhadap Kesiapan Kerja Calon Akuntan di Era Disrupsi Teknologi Digital. 5(September), 449-456. https://doi.org/10.33087/ekonomis.v5i2.389 